\title{
Renal Association Clinical Practice Guideline on Prevention of Blood Borne Virus Infection in the Renal Unit
}

\author{
Dr Colin Geddes ${ }^{a}$, Dr Elizabeth Lindley ${ }^{b}$ and Dr Neill Duncan ${ }^{c}$ \\ ${ }^{a}$ Consultant Nephrologist, NHS Greater Glasgow \& Clyde \\ ${ }^{\mathrm{b}}$ Clinical Scientist, Leeds Teaching Hospitals \\ ${ }^{c}$ Consultant Nephrologist, Imperial College Healthcare NHS Trust
}

\section{Key Words}

Blood borne virus $\cdot$ dialysis patients - hepatitis $B \cdot$ hepatitis $C$ $\cdot$ universal precautions

\section{Introduction}

Blood borne virus (BBV) infection was recognised as an important hazard for patients and staff in renal units in the 1960s [1]. In 1972 the Rosenheim Report was commissioned by the precursor to what is now the Department of Health (DoH) and included a set of guidelines for the control of hepatitis B (HBV) infection in renal units [2]. In 2002 a working party convened by the Public Health Laboratory Service (PHLS) on behalf of the Department of Health published an updated report that also included recommendations related to hepatitis $\mathrm{C}$ (HCV) and human immunodeficiency virus (HIV) infection [3]. The following clinical practice guideline has considerable overlap with the DoH 2002 recommendations. It also complements other recently published international guidelines including Kidney Disease Improving Global Outcomes (KDIGO) guidelines for Hepatitis C [4] and Canadian Society of Nephrology guidelines for prevention of blood borne infections in dialysis units (http://csnscn.ca/english/professional\%20 practice/guidelines/default.asp?s=1, accessed 24/11/2008). Other evidence has been identified by on-line literature searching of Medline and Embase from 1966-2008. The draft guideline was posted on the Renal Association website between February and June 2009 and redrafted in the light of feedback from interested parties (see 'Acknowledgements' section).

The evidence for these recommendations has been assessed using the modified GRADE system. The modified GRADE system defines both the strength of the recommendations of the guideline authors and the level of evidence upon which each of the recommendations is based. This grading system classifies
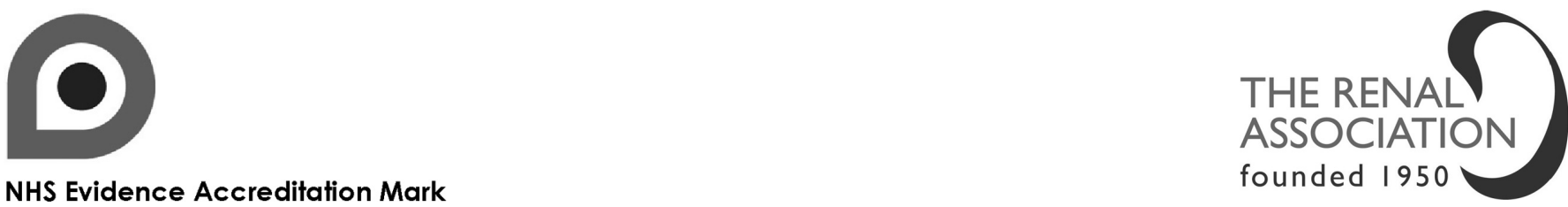

NHS Evidence Accreditation Mark

Dr Colin Geddes

Email: colin.geddes@ggc.nhs.uk 
expert recommendations as 'strong' (Grade 1) or 'weak' (Grade 2) based upon the balance between the benefits and risks, burden and cost. The quality or level of evidence is designated as high (Grade A), moderate (Grade B), low (Grade C) or very low (D) depending on factors such as study design, directness of evidence and consistency of results. Grades of recommendation and quality of evidence may range from $1 \mathrm{~A}$ to $2 \mathrm{D}$. The GRADE system has been developed by an international group of guideline developers and methodologists to improve the usefulness of clinical practice guidelines in the management of typical patients.

The incidence of HBV and $\mathrm{HCV}$ in dialysis units has fallen over the last 3 decades [5-7] although data from USA showed that the incidence of HBV infection in dialysis units had stayed stable at $1 \%$ per year in the 10 years before 2002 [8]. Most UK renal health care workers have probably never witnessed an outbreak of $\mathrm{BBV}$ in the renal unit. However, the ever increasing prevalence of patients on haemodialysis [9], the increase in migration of patients from other countries and the relative ease of foreign travel for dialysis patients means that renal units need to be increasingly alert to the possibility of BBV transmission. A substantial part of the reduction in the incidence of BBV infection in renal units has been associated with the implementation of so-called 'universal', or 'standard', precautions for prevention of BBV transmission. However, there continues to be numerous reports of outbreaks of BBV infection in renal units worldwide and often there is evidence that these have been caused by lapses in high standards of infection control practice [10-15].

The main risks relate to Hepatitis B (HBV), Hepatitis $\mathrm{C}$ (HCV) and human immunodeficiency virus (HIV) infections. These viruses have been associated with outbreaks among patients and staff in haemodialysis units. Other BBV such as Hepatitis G and GB virus type C have been identified as being more commonly carried in dialysis patients than the general population but their clinical significance is uncertain [16-18]. Risk of $\mathrm{BBV}$ transmission is known to be directly related to the concentration of virus in the blood. HCV and HIV are less infectious in dialysis units than HBV but outbreaks have been reported $[11,12,14,19-23]$ emphasising the need for infection control measures. Patients with any acute BBV infection are probably more infectious than chronic carriers and this guideline therefore includes recommendations to try to identify patients at risk of acute BBV infection.

Minimising the incidence of BBV transmission in renal units is the aim of this clinical practice guideline. The incidence has been so low that it is not feasible to design controlled clinical trials to test measures to reduce it further. Therefore most of the evidence to support the recommendations comes from observational clinical studies, case series and in vitro observations. For example multicentre and single centre observational studies demonstrate impressive reduction of the incidence of BBV infection in association with the introduction of a range of infection control measures [24-27]. This is encouraging but it is not possible to determine which of the infection control measures had the biggest impact. The recommendations also take in to account the resources that can realistically be expected in UK renal units: e.g. a dialysis nurse to patient ratio of $1: 1$ would probably reduce the risk of BBV transmission but is not recommended as it is not feasible. Similarly, when recommending areas for future research we have chosen not to recommend interventional controlled trials that are unfeasible.

When applying this clinical practice guideline it is important to consider the balance between protecting patients from the risks of BBV transmission and compromising clinical care of patients infected, or at high risk of infection with BBV especially with regards to segregation.

This guideline does not cover treatment of BBV in patients with chronic kidney disease (CKD) or prevention of $\mathrm{BBV}$ infection in patients receiving kidney transplants. Organisation of HBV immunisation and organisation of enhanced surveillance after dialysis in another country can be challenging in busy renal units and so we have included algorithm templates that units can use to address this (appendix 1 and appendix 2). 


\section{References}

$>1$ Knight AH, Fox RA, Baillod RA et al. Hepatitis-associated antigen and antibody in haemodialysis patients and staff. British Medical Journal 1970;3:603-606

2 Report of the Rosenheim Advisory Group. Hepatitis and the treatment of chronic renal failure. 1972. Department of Health and Social Security

3 Recommendations of a working group convened by the Public Health Laboratory Service (PHLS) on behalf of the Department of Health. Good Practice Guidelines for Renal Dialysis/Transplantation Units. Prevention and control of blood-borne virus infection. 2002

$\checkmark 4$ Kidney Disease: Improving Global Outcomes. KDIGO clinical practice guidelines for the prevention, diagnosis, evaluation, and treatment of Hepatitis C in chronic kidney disease. Kidney Int 2008;73:S1-S99

5 Tokars JI, Alter MJ, Favero MS, Moyer LA, Bland LA. National surveillance of dialysis associated diseases in the United States, 1991. ASAIO J 1993;39:966-975

6 Tokars JI, Alter MJ, Favero MS, Moyer LA, Bland LA. National surveillance of hemodialysis associated diseases in the United States, 1990. ASAIO J 1993;39:71-80

7 Jadoul M, Poignet JL, Geddes C et al. The changing epidemiology of hepatitis $\mathrm{C}$ virus (HCV) infection in haemodialysis: European multicentre study. Nephrol Dial Transplant 2004;19:904-909

-8 Finelli L, Miller JT, Tokars JI, Alter MJ, Arduino MJ. National surveillance of dialysis-associated diseases in the United States, 2002. Semin Dial 2005;18:52-61

9 Farrington K, Hodsman A, Steenkamp R, Feest T, Feehally J. All patients receiving renal replacement therapy in the United Kingdom 2006. In: Ansell D, Feehally J, Feest TG, Tomson C, Williams AJ, Warwick G, eds. UK Renal Registry Report 2007. Bristol, UK: UK Renal Registry; 2007;48

$>10$ Teles SA, Martins RM, Vanderborght B, Stuyver L, Gaspar AM, Yoshida CF. Hepatitis B virus: genotypes and subtypes in Brazilian hemodialysis patients. Artif Organs 1999;23:1074-1078

$\checkmark 11$ Spada E, Abbate I, Sicurezza E et al. Molecular epidemiology of a hepatitis $\mathrm{C}$ virus outbreak in a hemodialysis unit in Italy. J Med Virol 2008;80:261-267

12 Castell J, Gutierrez G, Castell J, Gutierrez G. [Outbreak of 18 cases of hepatitis $\mathrm{C}$ in a hemodialysis unit]. [Spanish]. Gaceta Sanitaria 2005;19:214-220

13 Ramalingam S, Leung T, Cairns H et al. Transmission of hepatitis B virus (genotype E) in a haemodialysis unit. Journal of Clinical Virology 2007;40:105-109

14 Kondili LA, Genovese D, Argentini C et al. Nosocomial transmission in simultaneous outbreaks of hepatitis $C$ and $B$ virus infections in a hemodialysis center. European Journal of Clinical Microbiology \& Infectious Diseases 2006;25:527-531
15 Irish DN, Blake C, Christophers J et al. Identification of hepatitis C virus seroconversion resulting from nosocomial transmission on a haemodialysis unit: implications for infection control and laboratory screening. Journal of Medical Virology 1999;59:135-140

16 Masuko K, Mitsui T, Iwano K et al. Infection with hepatitis GB virus C in patients on maintenance hemodialysis. N Engl J Med 1996;334:14851490

17 Schlaak JF, Kohler H, Gerken G. Hepatitis G virus: an old, but newly discovered hepatotropic virus - is it of interest for the nephrologist? Nephrol Dial Transplant 1996;11:1522-1523

18 Hosseini-Moghaddam SM, Keyvani H, Samadi M et al. GB virus type $\mathrm{C}$ infection in hemodialysis patients considering co-infection with hepatitis C virus. Journal of Medical Virology 2008;80:1260-1263

19 Velandia M, Fridkin SK, Cardenas V et al. Transmission of HIV in dialysis centre. Lancet 1995;345:1417-1422

20 El Sayed NM, Gomatos PJ, Beck-Sague CM et al. Epidemic transmission of human immunodeficiency virus in renal dialysis centers in renal dialysis centers in Egypt. J Infect Dis 2000;181:91-97

21 McLaughlin KJ, Cameron SO, Good T et al. Nosocomial transmission of hepatitis $\mathrm{C}$ virus within a British dialysis centre. Nephrol Dial Transplant 1997;12:304-309

22 Hmaied F, Ben Mamou M, Saune-Sandres K et al. Hepatitis C virus infection among dialysis patients in Tunisia: incidence and molecular evidence for nosocomial transmission. Journal of Medical Virology 2006;78:185-191

23 Sartor C, Brunet P, Simon S et al. Transmission of hepatitis C virus between hemodialysis patients sharing the same machine. Infection Control \& Hospital Epidemiology 2004;25:609-611

24 Stragier A, Jadoul M. Should dialysis machines be disinfected between patients' shifts? Edtna-Erca Journal 2003;29:73-76

25 Karkar A, Abdelrahman M, Ghacha R et al. Prevention of viral transmission in HD units: the value of isolation. Nasrat Amrad Wa Ziraat Alkulat 2006;17:183-188

26 Marcus R, Favero MS, Banerjee S et al. Prevalence and incidence of human immunodeficiency virus among patients undergoing longterm hemodialysis. The Cooperative Dialysis Study Group. American Journal of Medicine 1991;90:614-619

27 Jadoul M, Cornu C, van Ypersele dS, Jadoul M, Cornu C, Ypersele de Strihou C. Universal precautions prevent hepatitis $\mathrm{C}$ virus transmission: a 54 month follow-up of the Belgian Multicenter Study. The Universitaires Cliniques St-Luc (UCL) Collaborative Group. Kidney International 1998;53:1022-1025 
Summary of Clinical Practice Guidelines

\section{Blood Borne Virus Infection (BBV Infection) (Guidelines BBV 1.1-1.2)}

Guideline 1.1 - BBV Infection: Prevention of spread to patients and staff in the renal unit (Universal precautions)

We recommend that infection-control procedures should include hygienic precautions that effectively prevent the transfer of blood or fluids contaminated with blood between patients either directly or via contaminated equipment or surfaces (often referred to as 'universal precautions'). (1A) (KDIGO Hepatitis C Guideline 3.2)

Guideline 1.2 - BBV Infection: Prevention of spread to patients and staff in the renal unit

We recommend that medicine vials should be discarded after single use or, if used for more than one patient, divided into multiple doses and distributed from a central area. (1B)

\section{Blood Borne Virus Infection (BBV Infection) (Guidelines BBV 2.1-2.5)}

\section{Guideline 2.1 - BBV Infection: Dialysis equipment}

We recommend that separate machines should be used for patients known to be infected with HBV (or at high risk of new HBV infection - see section 3.7 and 3.8 below). A machine that has been used for HBV patients can be used again for non-infected patients only after it has been thoroughly decontaminated. (1A)

\section{Guideline 2.2 - BBV Infection: Dialysis equipment}

We recommend that dedicated machines are not required for patients with HCV or HIV provided that disinfection processes are properly carried out between patients according to a local protocol that incorporates the manufacturer's instructions. (1B) (KDIGO Hepatitis C guideline 3.1)

\section{Guideline 2.3 - BBV Infection: Dialysis equipment}

We recommend that dialysers manufactured for multiple use can be re-used provided there is implementation of, and adherence to, strict infection control procedures to avoid dialysers or blood port caps being switched between patients. (1C) (KDIGO Hepatitis C guideline 3.1)
Guideline 2.4-BBV Infection: Dialysis equipment

We suggest that external transducer protectors on the blood circuit pressure monitoring lines should be inspected by healthcare personnel during and after each dialysis session. If there is evidence of breach by blood or saline then the machine should be taken out of service and machine components that may have come in contact with blood should be replaced or decontaminated by qualified personnel according to a protocol that incorporates the manufacturers' instructions. (2C)

\section{Guideline 2.5 - BBV Infection: Dialysis equipment}

We recommend that the dialysis machine should be cleaned between patients according to a local protocol that incorporates the manufacturer's instructions. (1C)

\section{Blood Borne Virus Infection (BBV Infection) (Guidelines BBV 3.1-3.12)}

Guideline 3.1 - BBV Infection: BBV surveillance in dialysis patients

We recommend that all patients starting haemodialysis (including patients with acute kidney injury) or returning to haemodialysis after another modality of renal replacement therapy should be known to be plasma HBV surface antigen ( $\mathrm{HbsAg}$ ) negative before having dialysis on the main dialysis unit. (1A)

\section{Guideline 3.2 - BBV Infection: BBV surveillance in} dialysis patients

We recommend that patients who require haemodialysis before the result of the HBsAg test is known should be dialysed in an area that is segregated from the main dialysis unit and the machine should not be used for another patient until the result is known to be negative or the machine has been decontaminated (see 2.1). (1A)

\section{Guideline 3.3 - BBV Infection: BBV surveillance in} dialysis patients

We recommend that patients on regular hospital haemodialysis who have responded to hepatitis B immunisation (annual anti HBs antibody titre $>10 \mathrm{mIU} / \mathrm{ml}$; see section 5 below), only need to be tested for HBsAg once a year. Non-responders should be tested at least every 3 months. (1C)

Guideline 3.4 - BBV Infection: BBV surveillance in dialysis patients

We recommend that patients on regular hospital haemodialysis should be tested for HCV antibody at 
least every 6 months. (1C) (KDIGO Hepatitis C guideline 1.2.2)

\section{Guideline 3.5 - BBV Infection: BBV surveillance in} dialysis patients

We recommend that antibody surveillance testing for HIV is not necessary for patients on regular hospital haemodialysis unless the patient is at high risk (see Table 2). (1C)

Guideline 3.6 - BBV Infection: BBV surveillance in dialysis patients

We suggest that patients who do not consent to BBV surveillance as described above should have dialysis in a segregated area unless they are known to be HBV immune. If patients who are known to be $\mathrm{HBV}$ immune do not consent to BBV surveillance then they should be managed in the same way as patients with $\mathrm{HCV}$ infection (see section 4). (2C)

Guideline 3.7 - BBV Infection: BBV surveillance in dialysis patients

We recommend that patients returning from dialysing outside the UK should have a risk assessment for potential exposure to BBV abroad. Where exposure is considered likely, enhanced surveillance testing for BBV should be instituted and patients should have dialysis in a segregated area until the HbsAg is known to be negative (see 3.8 below) unless they are known to be HBV immune (antiHBs $>100 \mathrm{mIU} / \mathrm{mL}$ within the last 12 months). (1B)

\section{Guideline 3.8 - BBV Infection: BBV surveillance in dialysis patients}

We recommend that enhanced surveillance in patients deemed to be at high risk after returning from abroad should consist of HCV RNA (or HCV core antibody) every 2 weeks for 3 months and, if not known to be $\mathrm{HBV}$ immune (anti-HBs $>100 \mathrm{mIU} / \mathrm{mL}$ within the last 12 months), HbsAg (or plasma HBV DNA) every 2 weeks for 3 months. Nucleic acid testing (NAT) for $\mathrm{HCV}$ and $\mathrm{HBV}$ in the first 1-2 months virtually excludes acute infection. If HIV is a possibility screening with 4th generation (antigen/antibody combination) assays should be used. (1B)

\section{Guideline 3.9 - BBV Infection: BBV surveillance in dialysis patients}

We recommend that patients at high risk for new BBV infection (see Table 2) should also have enhanced surveillance as described in 3.8. (1B)

Prevention of Blood Borne Virus Infection in the Renal Unit
Guideline 3.10 - BBV Infection: BBV surveillance in dialysis patients

We recommend that testing for HBV DNA and HCV RNA should be performed in haemodialysis patients with unexplained abnormal serum aminotransferase concentrations. (1B) (KDIGO Hepatitis C guideline 1.2.3)

\section{Guideline 3.11 - BBV Infection: BBV surveillance in} dialysis patients

We recommend that, if a new BBV infection in a haemodialysis unit is identified, testing for viral RNA or DNA should be performed in all patients who may have been exposed (see section 7). (1B) (KDIGO Hepatitis $\mathrm{C}$ guideline 1.2.4)

Guideline 3.12 - BBV Infection: BBV surveillance in dialysis patients

We recommend that testing for HCV antibody should be by third generation ELISA. (1B)

\section{Blood Borne Virus Infection (BBV Infection) (Guidelines BBV 4.1-4.3)}

\section{Guideline 4.1 - BBV Infection: Segregation of patients infected with $B B V$ or at high risk for new $B B V$ infection}

We recommend that patients infected with HBV should be dialysed in an area that is segregated from the main dialysis unit. (1A)

\begin{abstract}
${ }^{a}$ The DoH report 2002 defined segregation between infected and clean areas in a renal unit as being 'functionally complete with no possibility of traffic between the two' and suggested there be a physical barrier such as walls or screens between these infected and clean areas.
\end{abstract}

Guideline 4.2 - BBV Infection: Segregation of patients infected with $B B V$ or at high risk for new $B B V$ infection

We recommend that healthcare workers performing dialysis on patients infected with HBV infection, whenever possible, should not dialyse patients without HBV infection at the same time. (1C)

\section{Guideline 4.3 - BBV Infection: Segregation of} patients infected with $B B V$ or at high risk for new $B B V$ infection

We recommend that patients with HCV or HIV do not need to be dialysed in a segregated area but more experienced staff should be allocated to dialyse these patients. (1C) If nosocomial transmission continues to

Nephron Clin Pract 2011;118(suppl 1):c165-c188 
occur, despite reinforcement and audit of the precautions listed in guidelines 1.1 and 1.2, a local segregation policy may be deemed necessary. HCV-infected patients should then be treated by dedicated staff in a separate room, area, or shift (morning, afternoon, or evening), as there is no rationale for using dedicated machines. It should be realized that accepting the 'need' for segregation equates to accepting the impossibility of full implementation of basic hygienic precautions, a regrettable situation that entails the risk of transmission of pathogens other than HCV. (KDIGO Hepatitis C guideline 3.1)

\section{Blood Borne Virus Infection (BBV Infection) (Guidelines BBV 5.1-5.8)}

\section{Guideline 5.1 - BBV Infection: Immunisation of patients against hepatitis $B$}

We recommend that patients who require renal replacement therapy (RRT) for CKD should be immunised against HBV. (1A)

\section{Guideline 5.2 - BBV Infection: Immunisation of patients against hepatitis $B$}

We recommend that patients who are likely to require RRT should be identified, whenever possible, early in the course of their disease to receive HBV immunisation. (1A)

\section{Guideline 5.3 - BBV Infection: Immunisation of patients against hepatitis $B$}

We suggest that patients who are at high risk for previous HBV infection should be known to have undetectable anti $\mathrm{HB}$ core antibody (anti $\mathrm{HBc}$ ) before administering an immunisation schedule. (2B)

\section{Guideline 5.4 - BBV Infection: Immunisation of patients against hepatitis $B$}

We recommend that the initial HBV immunisation schedule should involve high doses, frequent doses or both (Fendrix $20 \mu$ g at $0,1,2$ and 6 months; Engerix B $40 \mu \mathrm{g}$ at $0,1,2$ and 6 months; or HBvaxPRO $40 \mu \mathrm{g}$ at 0,1 and 6 months). (1A)

\section{Guideline 5.5 - BBV Infection: Immunisation of patients against hepatitis $B$}

We recommend that the vaccines are licensed for intramuscular route (deltoid muscle) but, if sufficient expertise exists, the intradermal route is more effective. (1A)
Guideline 5.6 - BBV Infection: Immunisation of patients against hepatitis $B$

We recommend that patients should be regarded as a 'responder' if anti HBs antibody titre is $>10 \mathrm{mIU} / \mathrm{mL} 8$ weeks after completing immunisation. (1C)

\section{Guideline 5.7 - BBV Infection: Immunisation of} patients against hepatitis $B$

We recommend that responders to HBV immunisation (as described in 5.6) should receive a further booster dose if the annual anti HBs titre is $<100 \mathrm{mIU} / \mathrm{mL}$. (1B)

\section{Guideline 5.8 - BBV Infection: Immunisation of patients against hepatitis $B$}

We recommend that non-responders to $\mathrm{HBV}$ as described in 5.6 should receive no further immunisation with currently available preparations. (1C)

\section{Blood Borne Virus Infection (BBV Infection) (Guidelines BBV 6.1-6.2)}

\section{Guideline 6.1 - BBV Infection: Immunisation of staff against hepatitis $B$}

We recommend that staff who have clinical contact with patients should be immunised against HBV and demonstrate that they are immune to, or not HBV infective. (1A)

Guideline 6.2 - BBV Infection: Immunisation of staff against hepatitis $B$

We suggest that staff who are not immune to HBV and are not HBV infective should ideally not dialyse patients who are HBV infective. (2B)

\section{Blood Borne Virus Infection (BBV Infection) \\ (Guidelines BBV 7.1-7.4)}

\section{Guideline 7.1 - BBV Infection: HD patients with new $B B V$ infection}

We recommend that, whenever a previously unidentified case of HBV infection is found, units should carry out enhanced HBV surveillance (as described in section 3.8) on all patients who are not immune to HBV (anti HBs titre $>100 \mathrm{mIU} / \mathrm{mL}$ within the last year) who have had a dialysis session since the index patient's last negative test. (1B)

Guideline 7.2 - BBV Infection: HD patients with new $B B V$ infection

We recommend that, whenever a previously unidentified case of HBV infection is found, those patients who 
have anti-HB titre $10-100 \mathrm{mIU} / \mathrm{ml}$ in the preceding 12 months who have had a dialysis session since the index patient's last negative test should also be given a booster dose of Hep B vaccine. Hepatitis B immunoglobulin (HBIG) should be considered for previous non-responders to Hepatitis B vaccine (anti-HBs $<10 \mathrm{mIU} / \mathrm{ml}$ ). (1B)

\section{Guideline 7.3 - BBV Infection: HD patients with new $B B V$ infection}

We recommend that, when a previously unidentified case of HCV is found, enhanced surveillance (as described in section 3.8) should be carried out in all patients who have had a dialysis session since the index patient's last negative test. (1C)

\section{Guideline 7.4-BBV Infection: HD patients with new $B B V$ infection}

We recommend that, when a haemodialysis patient develops a new BBV infection, expert virological advice should be obtained to co-ordinate enhanced surveillance of at-risk dialysis patients and carers and to arrange treatment of affected individuals. (1C)

\section{Summary of Audit Measures}

1. National survey of dialyser re-use in dialysis units

2. How frequent is contamination of external pressure monitor filters with blood or saline observed during haemodialysis sessions and what are the factors associated with contamination?

3. What proportion of prevalent dialysis patients are known to be immune to HBV (anti HBs $>10 \mathrm{mU} / \mathrm{mL}$ within the last year). Of the remainder, what proportion has a HBsAg test result from within the last 3 calendar months?

4. What proportion of patients known to be infected with HBV are dialysed in a segregated area (using the DoH definition of 'segregated')?

5. The proportion of incident patients starting regular hospital haemodialysis who have anti HBs antibody titre $>10 \mathrm{mIU} / \mathrm{mL}$

6. The proportion of patients with eGFR $<30 \mathrm{ml} / \mathrm{min}$ and are expected to require RRT who have initiated a HBV immunisation schedule 


\section{Full Clinical Practice Guidelines}

\section{Blood Borne Virus Infection (BBV Infection) (Guidelines BBV 1.1-1.2)}

\section{Guideline 1.1 - BBV Infection: Prevention of spread to patients and staff in the renal unit (Universal precautions)}

We recommend that infection-control procedures should include hygienic precautions that effectively prevent the transfer of blood or fluids contaminated with blood between patients either directly or via contaminated equipment or surfaces (often referred to as 'universal precautions'). (1A) (KDIGO Hepatitis C Guideline 3.2)

\section{Rationale}

BBV can survive and remain potentially infective on the surfaces of clinical equipment even though splashes of blood may not be visible to the naked eye $[1,2]$. HCV RNA has been detected on the hands of nurses dialysing infected patients [3]. Whilst HBV DNA and HCV RNA have been detected in dialysate of patients known to have these infections there is no evidence that the internal fluid pathways offer a viable route for transmission of BBV $[4,5]$.

Units should adopt the highest standards of infection control as laid out in DoH regulations (http://www.hse. gov.uk/healthservices/index.htm; accessed November 2008) and in the KDIGO guidelines for hepatitis C [6]. Universal precautions include hand washing after each patient contact and after contact with blood or body fluids; wearing of disposable gloves when working with blood or body fluids; wearing of disposable plastic aprons/impermeable gowns when splashing with blood or body fluids may occur; eye protection (visors, goggles, or safety spectacles) when blood, body fluids or flying contaminated debris/tissue might splash into the face; covering any cuts or abrasions with waterproof plasters; immediate and safe disposal of sharps into appropriate puncture-proof sharps bins; not overfilling sharps containers; and never re-sheathing needles. Implementing these precautions will require a plentiful supply of protective equipment, adequate handwashing facilities and adequate nursing and cleaning staff. Particular attention should be paid to the layout of the dialysis unit, lighting and the flow of 'traffic'. Every effort should be made to avoid staff rushing clinical care, to minimise the opportunity for accidental transmission of blood from one patient to another. Studies in Italian [7] and Saudi Arabian [8] haemodialysis centres revealed a significant association between the incidence and prevalence of HCV and the nurse patient ratio, suggesting that staffing plays a role in transmission.

Renal units should establish protocols for cleaning and disinfecting exposed surfaces and equipment in the dialysis unit with neutral detergent and hot water between patient treatments. For each chemical cleaning and disinfectant agent units should follow the manufacturer's instructions regarding appropriate dilution and contact time. Any blood spillage should be immediately cleaned with a cloth soaked with an anti-microbial disinfectant or bleach. Shared equipment should be cleaned according to manufacturers' instructions.

Implementation of these simple measures described above has been shown to be effective in preventing transmission when a patient has contracted BBV outside the renal unit and dialysed in the unit until BBV was detected by surveillance [9].

\section{Guideline 1.2 - BBV Infection: Prevention of spread to patients and staff in the renal unit (Universal precautions)}

We recommend that medicine vials should be discarded after single use or, if used for more than one patient, divided into multiple doses and distributed from a central area. (1B)

\section{Rationale}

The use of multi-dose vials of medicines such as heparin and lignocaine has been associated with avoidable outbreaks of HBV in dialysis units by facilitating needle contamination of the vial with an infected patient's blood that is then transmitted to another patient via another needle $[10,11]$. To avoid this risk, medicines should be prepared and distributed from a central area rather than at the dialysis station [12]. 


\section{References}

1 Favero MS, Maynard JE, Petersen NJ et al. Letter: Hepatitis-B antigen on environmental surfaces. Lancet 1973;2:1455

-2 Froio N, Nicastri E, Comandini UV et al. Contamination by hepatitis B and $\mathrm{C}$ viruses in the dialysis setting. Am J Kidney Dis 2003;42:546-550

$\checkmark 3$ AlFurayh O, Sabeel A, Al Ahdal MN et al. Hand contamination with hepatitis $\mathrm{C}$ virus in staff looking after hepatitis $\mathrm{C}$-positive hemodialysis patients. Am J Nephrol 2000;20:103-106

$\checkmark 4$ Kroes AC, van Bommel EF, Niesters HG, Weimar W. Hepatitis B viral DNA detectable in dialysate. Nephron 1994;67:369

5 Valtuille R, Fernandez JL, Berridi J et al. Evidence of hepatitis C virus passage across dialysis membrane. Nephron 1998;80:194-196

6 Kidney Disease: Improving Global Outcomes. KDIGO clinical practice guidelines for the prevention, diagnosis, evaluation, and treatment of Hepatitis C in chronic kidney disease. Kidney Int 2008;73:S1-S99

7 Petrosillo N, Gilli P, Serraino D et al. Prevalence of infected patients and understaffing have a role in hepatitis $\mathrm{C}$ virus transmission in dialysis.[see comment]. American Journal of Kidney Diseases 2001;37: 1004-1010
-8 Saxena AK, Panhotra BR. The impact of nurse understaffing on the transmission of hepatitis $\mathrm{C}$ virus in a hospital-based hemodialysis unit. Med Princ Pract 2004;13:129-135

$\checkmark 9$ Kroes AC, van Bommel EF, Kluytmans JA et al. Hepatitis B and hemodialysis: the impact of universal precautions in preventing the transmission of bloodborne viruses. Infection Control \& Hospital Epidemiology 1998;19:508-510

10 Alter MJ, Ahtone J, Maynard JE. Hepatitis B virus transmission associated with a multiple-dose vial in a hemodialysis unit. Ann Intern Med 1983;99:330-333

11 Kokubo S, Horii T, Yonekawa O, Ozawa N, Mukaide M. A phylogenetictree analysis elucidating nosocomial transmission of hepatitis $\mathrm{C}$ virus in a haemodialysis unit. J Viral Hepat 2002;9:450-454

12 Tokars JI, Finelli L, Alter MJ, Arduino MJ. National surveillance of dialysis-associated diseases in the United States, 2001. Semin Dial 2004;17:310-319 


\section{Blood Borne Virus Infection (BBV Infection) (Guidelines BBV 2.1-2.5)}

\section{Guideline 2.1 - BBV Infection: Dialysis equipment}

We recommend that separate machines should be used for patients known to be infected with HBV (or at high risk of new HBV infection - see section 3.7 and 3.8 below). A machine that has been used for HBV patients can be used again for non-infected patients only after it has been thoroughly decontaminated. (1A)

\section{Rationale}

It makes sense to use separate machines for patients infected with HBV because of the high infectivity of HBV and the ability of HBV to survive on clinical surfaces [1]. The same logic should apply to other pieces of equipment such as the dialysis chair.

Standard disinfection of machines between patients does not eliminate the risk of transmission of HBV [2]. A machine that has been used for HBV patients can be used again for non-infected patients only after it has been thoroughly decontaminated. A local protocol for decontamination should be drawn up, taking into account the manufacturer's instructions, the design of the machine and the use of double transducer protectors. If the machine does not automatically disinfect the Hansen connectors, they should be disinfected manually (e.g. by immersion in bleach for 10 minutes). If the machine housing is known to have points that are vulnerable to blood seepage, these should be checked and disinfected. The pressure transducer ports should be decontaminated unless double transducer protectors are routinely used.

\section{Guideline 2.2 - BBV Infection: Dialysis equipment}

We recommend that dedicated machines are not required for patients with HCV or HIV provided that disinfection processes are properly carried out between patients according to a local protocol that incorporates the manufacturer's instructions. (1B) (KDIGO Hepatitis C guideline 3.1)

\section{Rationale}

The risk of sharing machines and other equipment is lower for HCV and HIV than HBV. Available evidence from large observational studies in several countries, including some with high BBV prevalence, indicates that standard disinfection between patients seems to be sufficient to prevent transmission of HCV when strict universal precautions are applied [3-6]. The same seems to be true for HIV although the evidence is limited [7].

\section{Guideline 2.3 - BBV Infection: Dialysis equipment}

We recommend that dialysers manufactured for multiple use can be re-used provided there is implementation of, and adherence to, strict infection control procedures to avoid dialysers or blood port caps being switched between patients. (1C) (KDIGO Hepatitis C guideline 3.1)

\section{Rationale}

Dialyser re-use is not currently practiced in the UK. It is possible that reprocessing will become more attractive for environmental reasons or through the introduction of a new generation of dialyser membranes, but units taking this route should only use dialysers that are approved for multiple use, There is evidence that dialyser re-use does not increase the risk of HCV infection if there is a robust mechanism to ensure the dialyser is not used for more than one patient $[4,8]$.

\section{Guideline 2.4-BBV Infection: Dialysis equipment}

We suggest that external transducer protectors on the blood circuit pressure monitoring lines should be inspected by healthcare personnel during and after each dialysis session. If there is evidence of breach by blood or saline then the machine should be taken out of service and machine components that may have come in contact with blood should be replaced or decontaminated by qualified personnel according to a protocol that incorporates the manufacturers' instructions. (2C)

\section{Rationale}

As a safety measure, pressure is routinely monitored at one or more points in the blood circuit during the dialysis treatment depending on the type of machine used. The current safety standards require pressure monitoring lines on the disposable blood tubing to have filters fitted to avoid the pressure sensing transducer of the machine coming in to direct contact with the patient's blood. Most machines also have internal protective filters between the pressure monitoring port (to which the line is connected) and the transducer, so that if there is a leak only the internal filter and associated tubing need to be replaced. It was previously thought that leaks associated with these protective systems were rare but recent evidence suggests that may not be the case [9-11]. There are some reports of nosocomial transmission of BBV that could implicate contamination of the dialysis machine due to undetected failures of the external filter $[12,13]$.

The filters used to protect the pressure transducers are designed to prevent cross contamination at bloodline 
pressures $<600 \mathrm{~mm}$ Hg. However, it appears that leaking of these filters ('breaches') can occur especially if wetting with saline or blood has compromised the integrity of the filter. Some bloodlines are fitted with filters that attach directly to the machine with no tubing between the filter and the machine. A breach may not be recognised unless the filter is visually inspected.

There are several measures that can reduce the risk of breach of these filters: monitoring the blood levels in the arterial and venous drip chambers during the haemodialysis session with adjustment as required to prevent overfilling; stopping the blood pump before resetting arterial or venous pressure alarms; and clamping the venous and arterial monitoring bloodlines before removing them from the machine at the end of the dialysis session. Some units now routinely add a second external transducer protector filter in series with the one already fitted to the pressure monitoring line which reduces the need for technical interventions that take the machine out of service.

In the unlikely event that the internal filter ruptures, the machine must be taken out of service and decontaminated according to a local protocol that incorporates the manufacturer's instructions.

\section{Guideline 2.5 - BBV Infection: Dialysis equipment}

We recommend that the dialysis machine should be cleaned between patients according to a local protocol that incorporates the manufacturer's instructions. (1C)

\section{Rationale}

Cleaning of dialysis machines between patients is a key component of the efforts to minimise the risk of BBV transmission in the renal unit. Dialysis units should

Table 1. KDIGO Hepatitis C guideline summary of hygienic precautions for dialysis machines. Reproduced from reference [4]

\begin{abstract}
Definitions
The 'transducer protector' is a filter (normally a hydrophobic $0.2-\mathrm{mm}$ filter) that is fitted between the pressure monitoring line of the extracorporeal circuit and the pressure monitoring port of the dialysis machine. The filter allows air to pass freely to the pressure transducer that gives the reading displayed by the machine, but it resists the passage of fluid. This protects the patient from microbiologic contamination (as the pressure monitoring system is not disinfected) and the machine from ingress of blood or dialysate. An external transducer protector is normally fitted to each pressure monitoring line in the blood circuit. A back-up filter is located inside the machine. Changing the internal filter is a technical job. A 'single-pass machine' is a machine that pumps the dialysate through the dialyser and then to waste. In general, such machines do not allow fluid to flow between the drain pathway and the fresh pathway except during disinfection. 'Recirculating' machines produce batches of fluid that can be passed through the dialyser several times.
\end{abstract}

\title{
Transducer protectors
}

External transducer protectors should be fitted to the pressure lines of the extracorporeal circuit. Before commencing dialysis, staff should ensure that the connection between the transducer protectors and the pressure-monitoring ports is tight as leaks can lead to wetting of the filter. Transducer protectors should be replaced if the filter becomes wet, as the pressure reading may be affected. Using a syringe to clear the flooded line may damage the filter and increase the possibility of blood passing into the dialysis machine so it is essential to fit a new transducer protector to the monitoring line if this procedure has to be used. If wetting of the filter occurs after the patient has been connected, the line should be inspected carefully to see if any blood has passed through the filter. If any fluid is visible on the machine side, the machine should be taken out of service at the end of the session so that the internal filter can be changed and the housing disinfected.

\section{External cleaning}

After each session, the exterior of the dialysis machine should be cleaned with a low-level disinfectant if not visibly contaminated. If a blood spillage has occurred, the exterior should be disinfected with a commercially available tuberculocidal germicide or a solution containing at least 500 p.p.m. hypochlorite (a 1:100 dilution of 5\% household bleach) if this is not detrimental to the surface of dialysis machines. Advice on suitable disinfectants, and the concentration and contact time required, should be provided by the manufacturer. If blood or fluid is thought to have seeped into inaccessible parts of the dialysis machine (for example, between modules, behind blood pump), the machine should be taken out of service until it can be dismantled and disinfected.

Disinfection of the internal fluid pathways

It is not necessary for the internal pathways of a single-pass dialysis machines to be disinfected between patients, unless a blood leak has occurred, in which case both the internal fluid pathways and the dialysate-to-dialyser (Hansen) connectors should be disinfected before the next patient. If machines are not subjected to an internal disinfection procedure, staff should ensure that sufficient time is available between patients for the external surfaces to be disinfected. Machines with recirculating dialysate should always be put through an appropriate disinfection procedure between patients. 
establish protocols for cleaning and disinfecting surfaces and equipment in the dialysis unit, including, where appropriate, careful mechanical cleaning before any disinfection process. For each chemical cleaning and disinfectant agent the manufacturer's instructions regarding appropriate dilution and contact time should be followed. The internal fluid pathways should also be cleaned according to the manufacturer's instructions.
HBV DNA and HCV RNA have been detected in dialysate of patients known to have these infections $[14,15]$ although it is doubtful if a contaminated dialysis fluid circuit has ever been the direct source of nosocomial infection.

The KDIGO Hepatitis C guidelines [16] included in Table 1 to summarise hygienic precautions for dialysis machines to minimise the risk of BBV transmission.

\section{References}

1 Favero MS, Maynard JE, Petersen NJ et al. Letter: Hepatitis-B antigen on environmental surfaces. Lancet 1973;2:1455

- 2 Tokars JI, Alter MJ, Miller E, Moyer LA, Favero MS. National surveillance of dialysis associated diseases in the United States - 1994. ASAIO J 1997;43:108-119

- 3 Gilli P, Soffritti S, De P, V et al. Prevention of hepatitis C virus in dialysis units. Nephron 1995;70:301-306

-4 Jadoul M, Cornu C, van Ypersele dS, Jadoul M, Cornu C, Ypersele de Strihou C. Universal precautions prevent hepatitis C virus transmission: a 54 month follow-up of the Belgian Multicenter Study. The Universitaires Cliniques St-Luc (UCL) Collaborative Group. Kidney International 1998;53:1022-1025

5 Jadoul M, Poignet JL, Geddes C et al. The changing epidemiology of hepatitis $\mathrm{C}$ virus (HCV) infection in haemodialysis: European multicentre study. Nephrol Dial Transplant 2004;19:904-909

6 Fissell RB, Bragg-Gresham JL, Woods JD et al. Patterns of hepatitis C prevalence and seroconversion in hemodialysis units from three continents: the DOPPS. Kidney International 2004;65:2335-2342

7 Marcus R, Favero MS, Banerjee S et al. Prevalence and incidence of human immunodeficiency virus among patients undergoing longterm hemodialysis. The Cooperative Dialysis Study Group. American Journal of Medicine 1991;90:614-619

- 8 Finelli L, Miller JT, Tokars JI, Alter MJ, Arduino MJ. National surveillance of dialysis-associated diseases in the United States, 2002. Semin Dial 2005;18:52-61
9 U.S.Food and Drug Administration. Center for Devices and Radiological Health. FDA safety alert: Potential cross-contamination linked to hemodialysis treatment.www.fdagov/cdrh/safety/althin html [serial online] 99 A.D.; Accessed August 25, 8 A.D

10 Health Canada: Therapeutic Products Directorate. Notice to hospitals: Hemodialysis units and blood tubing sets incorporating a transducer protector. Health Canada [serial online] 2004;Accessed September 2, 2008

11 Brunet P, Frenkian G, Girard AM et al. [Backward flow of blood in the extracorporal circuit pressure transducers of the generator-monitors of hemodialysis]. [French]. Nephrologie et Therapeutique 2005;1:157-160

12 Delarocque-Astagneau E, Baffoy N, Thiers Vet al. Outbreak of hepatitis C virus infection in a hemodialysis unit: potential transmission by the hemodialysis machine? Infect Control Hosp Epidemiol 2002;23:328-334

13 Savey A, Simon F, Izopet J et al. A large nosocomial outbreak of hepatitis $C$ virus infections at a hemodialysis center.[erratum appears in Infect Control Hosp Epidemiol. 2005 Oct; 26(10):810]. Infection Control \& Hospital Epidemiology 2005;26:752-760

14 Kroes AC, van Bommel EF, Niesters HG, Weimar W. Hepatitis B viral DNA detectable in dialysate. Nephron 1994;67:369

15 Valtuille R, Fernandez JL, Berridi J et al. Evidence of hepatitis C virus passage across dialysis membrane. Nephron 1998;80:194-196

16 Kidney Disease: Improving Global Outcomes. KDIGO clinical practice guidelines for the prevention, diagnosis, evaluation, and treatment of Hepatitis C in chronic kidney disease. Kidney Int 2008;73:S1-S99 


\section{Blood Borne Virus Infection (BBV Infection) (Guidelines BBV 3.1-3.12)}

\section{Guideline 3.1 - BBV Infection: BBV surveillance in dialysis patients}

We recommend that all patients starting haemodialysis (including patients with acute kidney injury) or returning to haemodialysis after another modality of renal replacement therapy should be known to be plasma HBV surface antigen ( $\mathrm{HbsAg}$ ) negative before having dialysis on the main dialysis unit. (1A)

\section{Guideline 3.2 - BBV Infection: BBV surveillance in dialysis patients}

We recommend that patients who require haemodialysis before the result of the HBsAg test is known should be dialysed in an area that is segregated from the main dialysis unit and the machine should not be used for another patient until the result is known to be negative or the machine has been decontaminated (see 2.1). (1A)

\footnotetext{
${ }^{a}$ The DoH report 20021 defined segregation between infected and clean areas in a renal unit as being 'functionally complete with no possibility of traffic between the two' and suggested there be a physical barrier such as walls or screens between these infected and clean areas.
}

\section{Guideline 3.3 - BBV Infection: BBV surveillance in dialysis patients}

We recommend that patients on regular hospital haemodialysis who are immune to hepatitis B immunisation (annual anti HBs antibody titre $>100 \mathrm{mIU} / \mathrm{ml}$; see section 5 below), only need to be tested for HBsAg once a year. Non-responders should be tested at least every 3 months. (1C)

\section{Guideline 3.4 - BBV Infection: BBV surveillance in dialysis patients}

We recommend that patients on regular hospital haemodialysis should be tested for HCV antibody at least every 6 months. (1C) (KDIGO Hepatitis C guideline 1.2.2)

\section{Guideline 3.5 - BBV Infection: BBV surveillance in dialysis patients}

We recommend that antibody surveillance testing for HIV is not necessary for patients on regular hospital haemodialysis unless the patient is at high risk (see Table 2). (1C)
Table 2. Patients at high risk for new BBV infection (adapted from American Association for the study of Liver Disease [4]

Who have injected illicit drugs recently

With other BBV infection

Unexplained abnormal aminotransferase levels

Who have recently received a kidney transplant or blood from a donor known to be infected with BBV

Who have sexual partners with BBV infection

Guideline 3.6 - BBV Infection: BBV surveillance in dialysis patients

We suggest that patients who do not consent to BBV surveillance as described above should have dialysis in a segregated area unless they are known to be HBV immune. If patients who are known to be $\mathrm{HBV}$ immune do not consent to BBV surveillance then they should be managed in the same way as patients with HCV infection (see section 4). (2C)

\section{Rationale ( for 3.1-3.6)}

Patients with established renal failure are often asymptomatic when infected by BBV and so a surveillance system is required to detect new BBV infection and implement measures to limit the opportunity for nosocomial spread $[1,2]$. The frequency of surveillance testing should be determined in part by the local prevalence and incidence of infection. The UK is a low prevalence country for BBV infection in patients with established renal failure and so surveillance can be less frequent than in higher risk countries [3]. However surveillance needs to be enhanced if the patient's overall risk is high or if the individual patient experiences an event that increases the risk. The definitions of high risk patients and high risk events applied in the recent KDIGO Hepatitis $\mathrm{C}$ guidelines were those of the American Association for the study of Liver Disease [4] (Table 2).

Previous guidelines have recommended HBsAg testing every 3 months for normal risk patients and the recent KDIGO guidelines recommend 6 monthly testing for $\mathrm{HCV}$ antibody using a 3rd generation assay [3]. The extremely low probability of acquiring HIV infection in UK dialysis units does not justify regular surveillance for otherwise low risk patients.

Testing for HBsAg is sufficient for the diagnosis of HBV infection in the majority of dialysis patients. However occult HBV infection (the presence of $\mathrm{HBV}$ DNA detectable by real time PCR in the absence of

Nephron Clin Pract 2011;118(suppl 1):c165-c188 
detectable HbsAg) has been reported in 3.8\% of chronic haemodialysis patients in one Canadian centre [5]. There are reports of transmission of $\mathrm{HBV}$ infection from patients with occult HBV infection though, to date, not in association with haemodialysis [6, 7]. As nucleic acid testing (NAT) testing becomes more widely available this is likely to be used to enhance HBV surveillance in renal units. For most units these surveillance measures will require agreements with virology laboratories to perform and report these screening tests at appropriate intervals.

\section{Guideline 3.7 - BBV Infection: BBV surveillance in dialysis patients}

We recommend that patients returning from dialysing outside the UK should have a risk assessment for potential exposure to BBV abroad. Where exposure is considered likely, enhanced surveillance testing for BBV should be instituted and patients should have dialysis in a segregated area until the HbsAg is known to be negative (see 3.8 below) unless they are known to be $\mathrm{HBV}$ immune (anti-HBs $>100 \mathrm{mIU} / \mathrm{mL}$ within the last 12 months). (1B)

\section{Guideline 3.8 - BBV Infection: BBV surveillance in dialysis patients}

We recommend that enhanced surveillance in patients deemed to be at high risk after returning from abroad should consist of HCV RNA (or HCV core antibody) every 2 weeks for 3 months and, if not known to be HBV immune (anti-HBs $>100 \mathrm{mIU} / \mathrm{mL}$ within the last 12 months), HbsAg (or plasma HBV DNA) every 2 weeks for 3 months. Nucleic acid testing (NAT) for $\mathrm{HCV}$ and $\mathrm{HBV}$ in the first 1-2 months virtually excludes acute infection. If HIV is a possibility screening with 4 th generation (antigen/antibody combination) assays should be used. (1B)

\section{Guideline 3.9 - BBV Infection: BBV surveillance in dialysis patients}

We recommend that patients at high risk for new BBV infection (see Table 2) should also have enhanced surveillance as described in 3.8. (1B)

\section{Guideline 3.10 - BBV Infection: BBV surveillance in dialysis patients}

We recommend that testing for HBV DNA and HCV RNA should be performed in haemodialysis patients with unexplained abnormal serum aminotransferase concentrations. (1B) (KDIGO Hepatitis C guideline 1.2.3)

Guideline 3.11 - BBV Infection: BBV surveillance in dialysis patients

We recommend that if a new $\mathrm{BBV}$ infection in a haemodialysis unit is identified, testing for viral RNA or DNA should be performed in all patients who may have been exposed (see section 7). (1B) (KDIGO Hepatitis $\mathrm{C}$ guideline 1.2.4)

\section{Guideline 3.12 - BBV Infection: BBV surveillance in dialysis patients}

We recommend that testing for HCV antibody should be by third generation ELISA. (1B)

\section{Rationale ( for 3.7-3.12)}

It makes sense to adopt the improved assays to detect acute BBV infection in patients at increased risk for BBV infection. Detection of HCV RNA by PCR techniques has now become more widely available [8]. This has the advantage of being more sensitive than $\mathrm{HCV}$ antibody detection and, in patients with acute infection, is detectable within 1-2 weeks of the acute infection which is up to six weeks before HCV antibody [4]. Furthermore, some patients with HCV infection do not develop detectable antibody. More recently still $\mathrm{HCV}$ detection by $\mathrm{HCV}$ core antigen $(\mathrm{HCV} \mathrm{CAg}$ ) has become available as a combination assay with $\mathrm{HCV}$ antibody. In acute infection $\mathrm{HCV} c \mathrm{Ag}$ becomes detectable only 2 days after HCV RNA and is an easier test to perform than HCV RNA detection by PCR $[9,10]$. Current evidence suggests that these more sensitive assays will be able to exclude acute infection more quickly in patients returning from high risk areas abroad but in the meantime we have continued with the previous recommendation for 3 months of enhanced surveillance. The false negative rate for third generation ELISA assays for HCV antibody is sufficiently low to make it still acceptable as the appropriate test for routine surveillance of haemodialysis patients $[3,8]$.

Judging the level of 'risk' for patients returning from haemodialysis units outside the UK is difficult and will inevitably involve a subjective assessment because the individuals who need to assess the risk will not be able to directly observe the measures in place to prevent BBV transmission within the unit being visited. Patients should be encouraged to discuss their travel plans with the dialysis unit staff well in advance. 


\section{Audit measure}

What proportion of prevalent patients are known to be immune to $\mathrm{HBV}$ (anti $\mathrm{HBs}>10 \mathrm{mU} / \mathrm{mL}$ within the last year). Of the remainder, what proportion has a HBsAg test result from within the last 3 calendar months?
Research

Survey of occult HBV and HCV infection in UK

\section{References}

1 Recommendations of a working group convened by the Public Health Laboratory Service (PHLS) on behalf of the Department of Health. Good Practice Guidelines for Renal Dialysis/Transplantation Units. Prevention and control of blood-borne virus infection. 2002

2 Roll M, Norder H, Magnius LO, Grillner L, Lindgren V. Nosocomial spread of hepatitis B virus (HBV) in a haemodialysis unit confirmed by HBV DNA sequencing. J Hosp Infect 1995;30:57-63

- 3 Kidney Disease: Improving Global Outcomes. KDIGO clinical practice guidelines for the prevention, diagnosis, evaluation, and treatment of Hepatitis C in chronic kidney disease. Kidney Int 2008;73:S1-S99

- 4 Strader DB, Wright T, Thomas DL, Seeff LB. Diagnosis, management, and treatment of hepatitis C. Hepatology 2004;39:1147-1171

5 Minuk GY, Sun DF, Greenberg R et al. Occult hepatitis B virus infection in a North American adult hemodialysis patient population. Hepatology 2004;40:1072-1077
6 Liu CJ, Chen DS, Chen PJ. Epidemiology of HBV infection in Asian blood donors: emphasis on occult HBV infection and the role of NAT. J Clin Virol 2006;36 Suppl 1:S33-S44

7 Liu CJ, Kao JH, Chen DS. Molecular assays for hepatitis B virus infection. Hepatology 2003;38:1311

8 Rahnavardi M, Hosseini Moghaddam SM, Alavian SM. Hepatitis C in hemodialysis patients: current global magnitude, natural history, diagnostic difficulties, and preventive measures. Am J Nephrol 2008;28:628-640

-9 Courouce AM, Le Marrec N, Bouchardeau F et al. Efficacy of HCV core antigen detection during the preseroconversion period. Transfusion 2000;40:1198-1202

10 Fabrizi F, de Vecchi AF, Como G et al. De novo HCV infection among dialysis patients: a prospective study by HCV core antigen ELISA assay. Alimentary Pharmacology \& Therapeutics 2005;21:861-869 


\section{Blood Borne Virus Infection (BBV Infection) (Guidelines BBV 4.1-4.3)}

\section{Guideline 4.1 - BBV Infection: Segregation of patients infected with $B B V$ or at high risk of new $B B V$ infection}

We recommend that patients infected with $\mathrm{HBV}$ should be dialysed in an area that is segregated from the main dialysis unit. (1A)

\begin{abstract}
${ }^{a}$ The DoH report 2002 defined segregation between infected and clean areas in a renal unit as being 'functionally complete with no possibility of traffic between the two' and suggested there be a physical barrier such as walls or screens between these infected and clean areas.
\end{abstract}

\section{Rationale}

There is ample evidence that suggests 'horizontal' (patients not sharing a machine) and 'vertical' (patients sharing a machine) transmission of HBV occurs when patients with $\mathrm{HBV}$ are dialysed beside uninfected patients $[1,2]$. The risk of HBV transmission has been shown to be reduced if patients with HBV are dialysed in an area that is segregated from the 'clean' area of the dialysis unit [3-5]. Transmission has been reported in situations where health workers care for infected and non-infected patients on the same haemodialysis shift.

\section{Guideline 4.2 - BBV Infection: Segregation of patients infected with $B B V$ or at high risk of new $B B V$ infection}

We recommend that healthcare workers performing dialysis on patients infected with HBV infection, whenever possible, should not dialyse patients without HBV infection at the same time. (1C)

\section{Guideline 4.3 - BBV Infection: Segregation of patients infected with $B B V$ or at high risk of new $B B V$ infection}

We recommend that patients with HCV or HIV do not need to be dialysed in a segregated area but more experienced staff should be allocated to dialyse these patients. (1C) If nosocomial transmission continues to occur, despite reinforcement and audit of the precautions listed in guidelines 1.1 and 1.2, a local segregation policy may be deemed necessary. HCV-infected patients should then be treated by dedicated staff in a separate room, area, or shift (morning, afternoon, or evening), as there is no rationale for using dedicated machines. It should be realized that accepting the 'need' for segregation equates to accepting the impossibility of full implementation of basic hygienic precautions, a regrettable situation that entails the risk of transmission of pathogens other than HCV. (KDIGO Hepatitis C guideline 3.1)

\section{Rationale ( for 4.2-4.3)}

As stated earlier the risk of nosocomial transmission appears to be much lower for HCV and HIV than HBV. In a study from Italy HCV RNA was detected on the outer surface of the inlet-outlet connector of a dialysis machine used for HCV non-infected patients but there no evidence of any patients becoming infected [6]. Data from the Dialysis Outcomes and Practice Patterns (DOPPS) study indicated that HCV seroconversion was not less likely when patients with $\mathrm{HCV}$ were segregated for haemodialysis [7]. Similarly a prospective multi-centre Belgian study showed that re-enforcement of universal precautions without segregation was sufficient to reduce the incidence of $\mathrm{HCV}$ infection from $1.41 \%$ to $0.8 \%$ [8] and this is supported by other observational studies [6,9-11]. In a large prospective multicentre study in the USA there were no cases of HIV infection in the subsequent year in centres where other patients with HIV were being dialysed with the implementation of universal precautions [12]. These observations are re-assuring but the numerous reports of HCV and HIV transmission in dialysis units [13-22] emphasise the importance of local monitoring of the implementation of infection control procedures outlined in sections 1 and 2 .

There is evidence from areas with a high prevalence of HCV infection that segregation is associated with reduced nosocomial infection both from a randomised control trial in Iran [23] and observational studies [2427] though isolation should not be seen as a substitute for strict contamination control procedures [28].

For a low BBV prevalence country like the UK it seems reasonable to propose segregation facilities are prioritised for patients with HBV infection but are also used for patients with HCV and HIV infection if there are concerns about the implementation of contamination control procedures.

The same principles should apply to patients with BBV who are admitted for in-patient care in the renal unit. Every effort must be made to ensure that these measures do not compromise the care of the patient being segregated. 


\section{References}

1 Recommendations of a working group convened by the Public Health Laboratory Service (PHLS) on behalf of the Department of Health. Good Practice Guidelines for Renal Dialysis/Transplantation Units. Prevention and control of blood-borne virus infection. 2002

- 2 Tokars JI, Alter MJ, Miller E, Moyer LA, Favero MS. National surveillance of dialysis associated diseases in the United States - 1994. ASAIO J 1997;43:108-119

3 Tokars JI, Alter MJ, Favero MS, Moyer LA, Bland LA. National surveillance of dialysis associated diseases in the United States, 1991. ASAIO J 1993;39:966-975

4 Hepatitis B in retreat from dialysis units in United Kingdom in 1973. Public Health Laboratory Service Survey. Br Med J 1976;1: 1579-1581

5 Najem GR, Louria DB, Thind IS et al. Control of hepatitis B infection. The role of surveillance and an isolation hemodialysis center. JAMA 1981;245:153-157

-6 Froio N, Nicastri E, Comandini UV et al. Contamination by hepatitis B and C viruses in the dialysis setting. Am J Kidney Dis 2003;42:546550

7 Fissell RB, Bragg-Gresham JL, Woods JD et al. Patterns of hepatitis C prevalence and seroconversion in hemodialysis units from three continents: the DOPPS. Kidney International 2004;65:2335-2342

8 Jadoul M, Cornu C, van Ypersele dS, Jadoul M, Cornu C, Ypersele de Strihou C. Universal precautions prevent hepatitis $C$ virus transmission: a 54 month follow-up of the Belgian Multicenter Study. The Universitaires Cliniques St-Luc (UCL) Collaborative Group. Kidney International 1998;53:1022-1025

$\checkmark 9$ Jadoul M, Poignet JL, Geddes C et al. The changing epidemiology of hepatitis $\mathrm{C}$ virus (HCV) infection in haemodialysis: European multicentre study. Nephrol Dial Transplant 2004;19:904-909

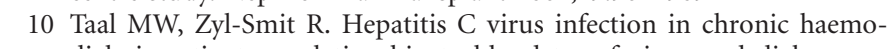
dialysis patients - relationship to blood transfusions and dialyser reuse. S Afr Med J 2000;90:621-625

11 Stragier A, Jadoul M. Should dialysis machines be disinfected between patients' shifts? Edtna-Erca Journal 2003;29:73-76

12 Marcus R, Favero MS, Banerjee S et al. Prevalence and incidence of human immunodeficiency virus among patients undergoing longterm hemodialysis. The Cooperative Dialysis Study Group. American Journal of Medicine 1991;90:614-619

13 Spada E, Abbate I, Sicurezza E et al. Molecular epidemiology of a hepatitis $\mathrm{C}$ virus outbreak in a hemodialysis unit in Italy. J Med Virol 2008;80:261-267

14 Allander T, Medin C, Jacobson SH, Grillner L, Persson MA. Hepatitis C transmission in a hemodialysis unit: molecular evidence for spread of virus among patients not sharing equipment. J Med Virol 1994;43: 415-419
15 Simon N, Courouce AM, Lemarrec N, Trepo C, Ducamp S. A twelve year natural history of hepatitis $\mathrm{C}$ virus infection in hemodialyzed patients. Kidney Int 1994;46:504-511

16 McLaughlin KJ, Cameron SO, Good T et al. Nosocomial transmission of hepatitis C virus within a British dialysis centre. Nephrol Dial Transplant 1997;12:304-309

17 Castell J, Gutierrez G, Castell J, Gutierrez G. [Outbreak of 18 cases of hepatitis C in a hemodialysis unit]. [Spanish]. Gaceta Sanitaria 2005;19:214-220

18 Kondili LA, Genovese D, Argentini C et al. Nosocomial transmission in simultaneous outbreaks of hepatitis C and B virus infections in a hemodialysis center. Eur J Clin Microbiol Infect Dis 2006;25:527-531

19 Velandia M, Fridkin SK, Cardenas V et al. Transmission of HIV in dialysis centre. Lancet 1995;345:1417-1422

20 El Sayed NM, Gomatos PJ, Beck-Sague CM et al. Epidemic transmission of human immunodeficiency virus in renal dialysis centers in Egypt. J Infect Dis 2000;181:91-97

21 Hmaied F, Ben Mamou M, Saune-Sandres K et al. Hepatitis C virus infection among dialysis patients in Tunisia: incidence and molecular evidence for nosocomial transmission. Journal of Medical Virology 2006;78:185-191

-22 Sartor C, Brunet P, Simon S et al. Transmission of hepatitis C virus between hemodialysis patients sharing the same machine. Infection Control \& Hospital Epidemiology 2004;25:609-611

23 Shamshirsaz AA, Kamgar M, Bekheirnia MR et al. The role of hemodialysis machines dedication in reducing Hepatitis $\mathrm{C}$ transmission in the dialysis setting in Iran: a multicenter prospective interventional study. BMC Nephrology 2004;5:13

24 Saxena AK, Panhotra BR. The impact of nurse understaffing on the transmission of hepatitis $\mathrm{C}$ virus in a hospital-based hemodialysis unit. Med Princ Pract 2004;13:129-135

25 Saxena AK, Panhotra BR, Sundaram DS et al. Impact of dedicated space, dialysis equipment, and nursing staff on the transmission of hepatitis $\mathrm{C}$ virus in a hemodialysis unit of the middle east. American Journal of Infection Control 2003;31:26-33

26 Gallego E, Lopez A, Perez J et al. Effect of isolation measures on the incidence and prevalence of hepatitis $\mathrm{C}$ virus infection in hemodialysis. Nephron 2006;104:c1-c6

27 Barril G, Traver JA, Barril G, Traver JA. Decrease in the hepatitis C virus (HCV) prevalence in hemodialysis patients in Spain: effect of time, initiating $\mathrm{HCV}$ prevalence studies and adoption of isolation measures. Antiviral Research 2003;60:129-134

28 Good Practice Guidelines for Renal Dialysis/Transplantation Units: Prevention and Control of Blood-borne Virus Infection Addendum, Guidelines for dialysis away from base (DAFB), Department of Health, October 2010. 


\section{Blood Borne Virus Infection (BBV Infection) (Guidelines BBV 5.1-5.8)}

\section{Guideline 5.1 - BBV Infection: Immunisation of patients against hepatitis $B$}

We recommend that patients who require renal replacement therapy (RRT) for CKD should be immunised against HBV. (1A)

\section{Rationale}

The introduction of HBV immunisation was associated with a reduction in the incidence of HBV infection in dialysis units [1]. A randomised controlled trial of immunisation suggested a reduction in $\mathrm{HBV}$ infection [2] and a case controlled study demonstrated a $70 \%$ reduction in HBV infection in patients who had received $\mathrm{HBV}$ immunisation compared with those who had not [3]. Despite the lower probability of HBV infection in peritoneal dialysis patients compared with HD patients [4] patients planning to have peritoneal dialysis should also be immunised as there is a sufficiently high probability that they will require haemodialysis at some point.

Passive immunisation with HBV immunoglobulin was previously shown to be effective in reducing the incidence of $\mathrm{HBV}$ infection in patients and staff in dialysis units [5] but this has now been superseded by active immunisation.

\section{Guideline 5.2 - BBV Infection: Immunisation of patients against hepatitis $B$}

We recommend that patients who are likely to require RRT should be identified, whenever possible, early in the course of their disease to receive HBV immunisation. (1A)

\section{Rationale}

The proportion of patients achieving adequate anti HBs antibody titres after immunisation is lower in patients with CKD than in the general population [68 ] and is lower in advanced CKD compared with milder stages of CKD [9-11].

\section{Guideline 5.3 - BBV Infection: Immunisation of patients against hepatitis $B$}

We suggest that patients who are at high risk for previous HBV infection should be known to have undetectable anti $\mathrm{HB}$ core antibody (anti $\mathrm{HBc}$ ) before administering an immunisation schedule. (2B)
Rationale

The need for pre-immunisation screening for anti $\mathrm{HBc}$ to avoid unnecessary immunisation should be guided by the likelihood that an individual has been exposed to HBV or previous vaccine as a study in the USA suggests that pre-immunisation screening is costeffective only in populations in which the prevalence of HBV infection exceeds 30\% [12]. Most patients in the UK therefore do not need pre-immunisation screening for anti $\mathrm{HBc}$.

\section{Guideline 5.4 - BBV Infection: Immunisation of patients against hepatitis $B$}

We recommend that the initial HBV immunisation schedule should involve high doses, frequent doses or both (Fendrix $20 \mu \mathrm{g}$ at $0,1,2$ and 6 months; Engerix B $40 \mu \mathrm{g}$ at $0,1,2$ and 6 months; or HBvaxPRO $40 \mu \mathrm{g}$ at 0,1 and 6 months). (1A)

\section{Guideline 5.5 - BBV Infection: Immunisation of patients against hepatitis $B$}

We recommend that the vaccines are licensed for intramuscular route (deltoid muscle) but, if sufficient expertise exists, the intradermal route is more effective. (1A)

\section{Rationale (for 5.4 and 5.5)}

There are several reports of increased success of immunisation if higher individual doses of vaccine are used, a greater number of doses are given and if the intradermal route is used [13-18]. Most studies have shown that a 4 dose double dose schedule over 6 months is superior to the conventional 3 dose immunisation schedule $[19,20]$. This is also logistically easier than identifying non-responders to the 3 dose schedule and administering a booster dose.

There is some evidence that HBV vaccine with the adjuvant ASO4 (Fendrix) is more immunogenic than Engerix B [21]. There has been recent interest in adding immunostimulants to improve the success of HBV immunisation in patients with CKD [22-25] but it is too early to make a firm recommendation and reports have, in some cases, had conflicting conclusions $[26,27]$.

\section{Guideline 5.6 - BBV Infection: Immunisation of patients against hepatitis $B$}

We recommend that patients should be regarded as a 'responder' if anti HBs antibody titre is $>10 \mathrm{mIU} / \mathrm{mL} 8$ weeks after completing immunisation. (1C) 


\section{Rationale}

Response should be assessed by measuring plasma anti HBs antibody 8 weeks after completion of the immunisation schedule. There is on-going debate about what constitutes a response to immunisation. Conventionally $>100 \mathrm{mIU} / \mathrm{ml}$ was regarded as conferring immunity but there is evidence that even patients who have a lower peak response $(10-100 \mathrm{mIU} / \mathrm{ml})$ will not become chronic carriers of HBV $[28,29]$. The significance of this titre was illustrated in a five-year follow-up study of 773 homosexual men vaccinated in 1980; most severe infections occurred among those who never achieved a titre $>9.9 \mathrm{mIU} / \mathrm{ml}$. The risk of late infection in those with an initial titre of $>9.9 \mathrm{mIU} / \mathrm{mL}$ increased markedly when antibody levels decreased below $10 \mathrm{mIU} / \mathrm{mL}$, but only 1 of 34 of these late infections resulted in viraemia and liver inflammation [29]. It is worth being aware of the possibility of HBV surface mutants that can cause HBV infection in patients with apparently adequate anti $\mathrm{HBs}$ titres and that seem to occur in endemic regions with large $\mathrm{HBV}$ vaccination programs (vaccine escape mutants) [30, 31].

\section{Guideline 5.7 - BBV Infection: Immunisation of patients against hepatitis $B$}

We recommend that responders to HBV immunisation (as described in 5.6) should receive a further booster dose if the annual anti HBs titre is $<100 \mathrm{mIU} / \mathrm{mL}$. (1B)

\section{Rationale}

More than half of haemodialysis patients who respond to immunisation do not maintain detectable antibody [32]. In one of the early randomised controlled studies of immunisation there were 4 cases of hepatitis B infection in dialysis patients who had an apparent response to immunisation in whom the antibody levels had waned, suggesting a strategy of antibody surveillance and booster doses may be worthwhile [2]. In one small Italian study the monitoring of antibody titers and the administration of additional doses enabled maintenance of protective HBV antibody levels in $96 \%$ of patients 4 years after initial immunisation [33].

Previous guidelines have also recommended annual testing of patients who have ever achieved a HBV titre $>10 \mathrm{mIU} / \mathrm{mL}$ with administration of a booster dose of vaccine if titre $<100 \mathrm{mIU} / \mathrm{ml}$ but we acknowledge that the frequency of surveillance and the titre to trigger a booster dose is debatable.

\section{Guideline 5.8 - BBV Infection: Immunisation of patients against hepatitis $B$}

We recommend that non-responders to $\mathrm{HBV}$ as described in 5.6 should receive no further immunisation with currently available preparations. (1C)

\section{Rationale}

The low prevalence of HBV infection in the UK makes maintenance of an immunisation program expensive. In the USA it has been estimated that there are 625 patients receiving immunisation per case prevented [34]. This means that efforts to induce immunity in patients who do not respond to a 4 dose double dose schedule are likely to be associated with an unacceptably high costbenefit ratio. However there is some recent evidence that non-responders to a 4 dose $40 \mu \mathrm{g}$ schedule might subsequently respond to a $160 \mu \mathrm{g}$ dose given intradermally [35].

\section{Audit measures}

- The prevalence of patients on regular hospital haemodialysis who have anti HBs antibody $>100 \mathrm{mIU} / \mathrm{mL}$ and $10-100 \mathrm{mIU} / \mathrm{mL}$ within the last year.

- The incidence of incident patients starting regular hospital haemodialysis who have anti HBs antibody titre $>100 \mathrm{mIU} / \mathrm{mL}$ and $10-100 \mathrm{mIU} / \mathrm{mL}$.

- The proportion of patients attending nephrology clinics with eGFR $<30 \mathrm{ml} / \mathrm{min}$, who are expected to require RRT, who have initiated a HBV immunisation schedule.

Research

- Natural history of antibody levels over time to determine optimal frequency of testing for anti HBs in HD patients.

- Impact on long-term antibody titres of strategies to enhance immune response to Hep B immunisation.

- Randomised controlled trials in non-responders to test novel methods to enhance immune response. 


\section{References}

1 Tokars JI, Alter MJ, Favero MS, Moyer LA, Bland LA. National surveillance of dialysis associated diseases in the United States, 1991. ASAIO J 1993;39:966-975

-2 Stevens CE, Alter HJ, Taylor PE et al. Hepatitis B vaccine in patients receiving hemodialysis. Immunogenicity and efficacy. New England Journal of Medicine 1984;311:496-501

3 Miller ER, Alter MJ, Tokars JI. Protective effect of hepatitis B vaccine in chronic hemodialysis patients. Am J Kidney Dis 1999;33:356-360

4 Cendoroglo NM, Draibe SA, Silva AE et al. Incidence of and risk factors for hepatitis B virus and hepatitis $\mathrm{C}$ virus infection among haemodialysis and CAPD patients: evidence for environmental transmission. Nephrol Dial Transplant 1995;10:240-246

$\checkmark 5$ Prince AM, Szmuness W, Mann MK et al. Hepatitis B immune globulin: final report of a controlled, multicenter trial of efficacy in prevention of dialysis-associated hepatitis. Journal of Infectious Diseases 1978;137: 131-144

6 Crosnier J, Jungers P, Courouce AM et al. Randomised placebo-controlled trial of hepatitis B surface antigen vaccine in French haemodialysis units: II, Haemodialysis patients. Lancet 1981;1:797-800

7 Crosnier J, Jungers P, Courouce AM et al. Randomised placebo-controlled trial of hepatitis B surface antigen vaccine in French haemodialysis units: I, Medical staff. Lancet 1981;1:455-459

8 Kohler H, Arnold W, Renschin G, Dormeyer HH, Meyer zum Buschenfelde $\mathrm{KH}$. Active hepatitis B vaccination of dialysis patients and medical staff. Kidney Int 1984;25:124-128

-9 DaRoza G, Loewen A, Djurdjev O et al. Stage of chronic kidney disease predicts seroconversion after hepatitis B immunization: earlier is better. Am J Kidney Dis 2003;42:1184-1192

10 Ridley L, Jones C. An audit of a programme of proactive pre-dialysis vaccination against hepatitis B. [abstract] Ridley L, Jones C. British Renal Congress 2008; Glasgow, May 2008

-11 Seaworth B, Drucker J, Starling J et al. Hepatitis B vaccines in patients with chronic renal failure before dialysis. Journal of Infectious Diseases 1988;157:332-337

12 Lemon SM, Thomas DL. Vaccines to prevent viral hepatitis. N Engl J Med 1997;336:196-204

13 Propst T, Propst A, Lhotta K, Vogel W, Konig P. Reinforced intradermal hepatitis B vaccination in hemodialysis patients is superior in antibody response to intramuscular or subcutaneous vaccination. Am J Kidney Dis 1998;32:1041-1045

14 Chau KF, Cheng YL, Tsang DN et al. Efficacy and side effects of intradermal hepatitis B vaccination in CAPD patients: a comparison with the intramuscular vaccination. Am J Kidney Dis 2004;43:910-917

- 15 Roozbeh J, Moini M, Lankarani KB, Sagheb MM, Shahpoori S, Bastani B. Low dose intradermal versus high dose intramuscular hepatitis $B$ vaccination in patients on chronic hemodialysis. ASAIO J 2005; 51:242-245

- 16 Bruguera M, Rodicio JL, Alcazar JM, Oliver A, Del RG, Esteban-Mur R. Effects of different dose levels and vaccination schedules on immune response to a recombinant DNA hepatitis B vaccine in haemodialysis patients. Vaccine 1990;8 Suppl:S47-S49

$\checkmark 17$ Fabrizi F, Andrulli S, Bacchini G, Corti M, Locatelli F. Intradermal versus intramuscular hepatitis $b$ re-vaccination in non-responsive chronic dialysis patients: a prospective randomized study with costeffectiveness evaluation. Nephrol Dial Transplant 1997;12:1204-1211

- 18 Oguz Y, Doganci L, Vural A. Seroconversion rates of two different doses of hepatitis B vaccine in Turkish haemodialysis patients. Cent Eur J Public Health 2001;9:44-45
19 Marangi AL, Giordano R, Montanaro A et al. Hepatitis B virus infection in chronic uremia: long-term follow-up of a two-step integrated protocol of vaccination. Am J Kidney Dis 1994;23:537-542

20 Charest AF, McDougall J, Goldstein MB. A randomized comparison of intradermal and intramuscular vaccination against hepatitis B virus in incident chronic hemodialysis patients. Am J Kidney Dis 2000;36: 976-982

21 Tong NK, Beran J, Kee SA et al. Immunogenicity and safety of an adjuvanted hepatitis $\mathrm{B}$ vaccine in pre-hemodialysis and hemodialysis patients. Kidney International 2005;68:2298-2303

22 Kong NC, Beran J, Kee SA et al. A new adjuvant improves the immune response to hepatitis $\mathrm{B}$ vaccine in hemodialysis patients. Kidney Int 2008;73:856-862

23 Singh NP, Mandal SK, Thakur A et al. Efficacy of GM-CSF as an adjuvant to hepatitis $B$ vaccination in patients with chronic renal failure - results of a prospective, randomized trial. Renal Failure 2003;25: 255-266

24 Kayatas M. Levamisole treatment enhances protective antibody response to hepatitis $\mathrm{B}$ vaccination in hemodialysis patients. Artif Organs 2002;26:492-496

25 Perez-Garcia R, Perez-Garcia A, Verbeelen D, Bernstein ED, Villarrubia VG, Alvarez-Mon M. AM3 (Inmunoferon) as an adjuvant to hepatitis B vaccination in hemodialysis patients. Kidney Int 2002;61:1845-1852

26 Evans TG, Schiff M, Graves B et al. The safety and efficacy of GM-CSF as an adjuvant in hepatitis B vaccination of chronic hemodialysis patients who have failed primary vaccination. Clinical Nephrology 2000;54: 138-142

27 Grob PJ, Binswanger U, Blumberg A et al. Thymopentin as adjuvant to hepatitis B vaccination. Results from three double-blind studies. Survey of Immunologic Research 1985;4 Suppl 1:107-115

28 Roll M, Norder H, Magnius LO, Grillner L, Lindgren V. Nosocomial spread of hepatitis B virus (HBV) in a haemodialysis unit confirmed by HBV DNA sequencing. J Hosp Infect 1995;30:57-63

29 Hadler SC, Francis DP, Maynard JE et al. Long-term immunogenicity and efficacy of hepatitis B vaccine in homosexual men. N Engl J Med 1986;315:209-214

30 Carman WF. The clinical significance of surface antigen variants of hepatitis B virus. J Viral Hepat 1997;4(suppl 1):11

31 Moal V, Vacher-Coponat H, Botelho E et al. Emergence of hepatitis B infection despite antibodies to hepatitis B surface antigen: a new nosocomial risk in patients with end-stage renal disease. Transplantation 2006;81:1358-1359

32 Fleming SJ, Moran DM, Cooksley WG, Faoagali JL. Poor response to a recombinant hepatitis B vaccine in dialysis patients. J Infect 1991;22: 251-257

33 Delle VM, Caraccio V, Iberti M et al. [Hepatitis B vaccine in dialyzed patients: persistence of antibody titres after a 48-month follow-up]. [Italian]. Minerva Urologica e Nefrologica 1996;48:47-50

34 Oddone EZ, Cowper PA, Hamilton JD et al. A cost-effectiveness analysis of hepatitis B vaccine in predialysis patients. Health Services Research 1993;28:97-121

35 Micozkadioglu H, Zumrutdal A, Torun D et al. Low dose intradermal vaccination is superior to high dose intramuscular vaccination for hepatitis B in unresponsive hemodialysis patients. Renal Failure 2007; 29:285-288 


\section{Blood Borne Virus Infection (BBV Infection) (Guidelines BBV 6.1-6.2)}

Guideline 6.1 - BBV Infection: Immunisation of staff against hepatitis $B$

We recommend that staff who have clinical contact with patients should be immunised against HBV and demonstrate that they are immune to, or not HBV infective. $(1 \mathrm{~A})$

Guideline 6.2 - BBV Infection: Immunisation of staff against hepatitis $B$

We suggest that staff who are not immune to HBV and are not HBV infective should ideally not dialyse patients who are HBV infective. (2B)
Rationale (for 6.1 and 6.2)

Several reports of outbreaks of HBV and HCV infection in dialysis units have included patient to staff and staff to patient transmission. Staff members are at much lower risk of acquiring HIV or HCV infection than HBV infection $[1,2]$. It is important, therefore to have a mechanism in place to minimise this risk. Hepatitis B immunisation of dialysis unit staff members has been shown to be effective in reducing the incidence of HBV infection in these staff members $[3,4]$. Staff who are in contact with clinical equipment that might be infected with HBV should also be offered HBV immunisation (e.g. dialysis technicians). Staff members are at very low risk of acquiring HIV or HCV from dialysis patients.

\section{References}

1 Petrosillo N, Puro V, Jagger J et al. The risks of occupational exposure and infection by human immunodeficiency virus, hepatitis B virus, and hepatitis $\mathrm{C}$ virus in the dialysis setting. Italian Multicenter Study on Nosocomial and Occupational Risk of Infections in Dialysis. American Journal of Infection Control 1995;23:278-285

2 Berlyne G, Kaczmarek RG, Hamburger S et al. Seroprevalence of antibodies to the human immunodeficiency virus in dialysis workers: results of a multi-center study. Nephron 1992;62:441-443
Szmuness W, Stevens CE, Harley EJ et al. Hepatitis B vaccine in medical staff of hemodialysis units: efficacy and subtype cross-protection. New England Journal of Medicine 1982;307:1481-1486

4 Crosnier J, Jungers P, Courouce AM et al. Randomised placebocontrolled trial of hepatitis B surface antigen vaccine in French haemodialysis units: I, Medical staff. Lancet 1981;1:455-459 


\section{Blood Borne Virus Infection (BBV Infection) (Guidelines BBV 7.1-7.4)}

\section{Guideline 7.1 - BBV Infection: HD patients with new $B B V$ infection}

We recommend that, whenever a previously unidentified case of HBV infection is found, units should carry out enhanced HBV surveillance (as described in section 3.8) on all patients who are not immune to HBV (anti HBs titre $>100 \mathrm{mIU} / \mathrm{mL}$ within the last year) who have had a dialysis session since the index patient's last negative test. (1B)

\section{Guideline 7.2 - BBV Infection: HD patients with new $B B V$ infection}

We recommend that, whenever a previously unidentified case of $\mathrm{HBV}$ infection is found, those patients who have anti-HB titre $10-100 \mathrm{mIU} / \mathrm{ml}$ in the preceding 12 months who have had a since the index patient's last negative test should also be given a booster dose of Hep B vaccine. Hepatitis B immunoglobulin (HBIG) should be considered for previous non-responders to Hepatitis B vaccine (anti-HBs $<10 \mathrm{mIU} / \mathrm{ml}$ ). (1B)

\section{Guideline 7.3 - BBV Infection: HD patients with new $B B V$ infection}

We recommend that, when a previously unidentified case of HCV is found, enhanced surveillance (as described in section 3.8) should be carried out in all patients who have had a dialysis session since the index patient's last negative test. (1C)

\section{Guideline 7.4-BBV Infection: HD patients with new $B B V$ infection}

We recommend that, when a haemodialysis patient develops a new BBV infection, expert virological advice should be obtained to co-ordinate enhanced surveillance of at-risk dialysis patients and carers and to arrange treatment of affected individuals. (1C)

\section{Rationale for 7.1-7.4}

Whenever a new case of blood borne virus infection is identified in the renal unit there is a risk that other patients may be incubating the same infection. For this reason it is necessary to perform enhanced surveillance of all at-risk patients [1-7]. In addition the risk of spread of Hepatitis $\mathrm{B}$ within the renal unit may be reduced by passive immunisation of non-responders to Hepatitis vaccine using Hepatitis B immunoglobulin and by the administration of a booster dose of Hepatitis vaccine to all patients who had borderline anti-Hepatitis B titres in the preceding 12 months. The assistance of the local virology service in co-ordinating surveillance and prevention measures is invaluable. The virology service should be requested to supervise the overall management of the new blood borne virus infection(s) until no further cases are detected.

\section{References}

1 Strader DB, Wright T, Thomas DL, Seeff LB. Diagnosis, management, and treatment of hepatitis C. Hepatology 2004;39:1147-1171

$\checkmark 2$ Minuk GY, Sun DF, Greenberg R et al. Occult hepatitis B virus infection in a North American adult hemodialysis patient population. Hepatology 2004;40:1072-1077

-3 Liu CJ, Chen DS, Chen PJ. Epidemiology of HBV infection in Asian blood donors: emphasis on occult HBV infection and the role of NAT. J Clin Virol 2006;36 Suppl 1:S33-S44

4 Liu CJ, Kao JH, Chen DS. Molecular assays for hepatitis B virus infection. Hepatology 2003;38:1311

\section{Acknowledgements}

We are grateful to Ray James, Maurice Harrington and Ian Morgan for their constructive comments on behalf of the UK Association of Renal Technologists.

Thanks are also due to Dr. Celia Aitken (Consultant Virologist), Stewart Campbell (Renal Technician), Dr. Robert Mactier (Consultant Nephrologist) and Dr. Paul
Rahnavardi M, Hosseini Moghaddam SM, Alavian SM. Hepatitis C in hemodialysis patients: current global magnitude, natural history, diagnostic difficulties, and preventive measures. Am J Nephrol 2008; 28:628-640

6 Courouce AM, Le Marrec N, Bouchardeau F et al. Efficacy of HCV core antigen detection during the preseroconversion period. Transfusion 2000;40:1198-1202

7 Fabrizi F, de Vecchi AF, Como G et al. De novo HCV infection among dialysis patients: a prospective study by HCV core antigen ELISA assay. Alimentary Pharmacology \& Therapeutics 2005;21:861-869

Leboi (Consultant Nephrologist) for helpful comments in the preparation of this clinical practice guideline.

\section{Declarations of interest}

Dr Geddes and Dr Duncan have no conflicts of interest to declare. Dr Lindley has received sponsorship to attend scientific and CME meetings from Shire, Amgen, Synermed, Genzyme and Fresenius. 
Appendix 1. Algorithm template for HBV immunisation

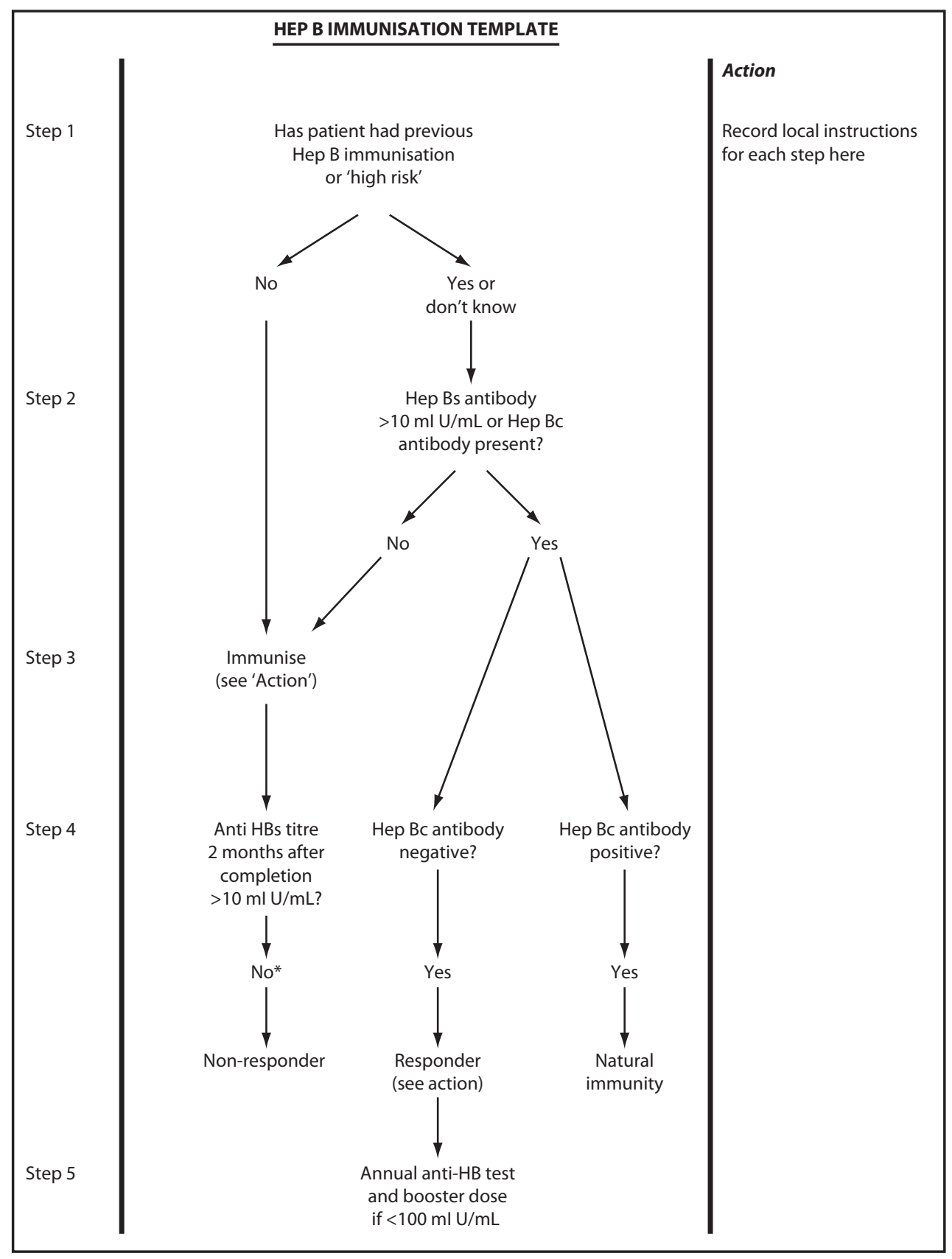


Appendix 2. Algorithm template for BBV testing after return from holiday dialysis

Blood borne virus testing in patients coming from other haemodialysis units (including return after holiday dialysis)

Action

(insert local actions)

All patients and machines should be segregated until known to be HBsAg, HCV antibody and HCV RNA negative before applying this algorithm

Is the patient coming

from 'high risk' unit?

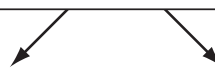

No

Yes or don't know

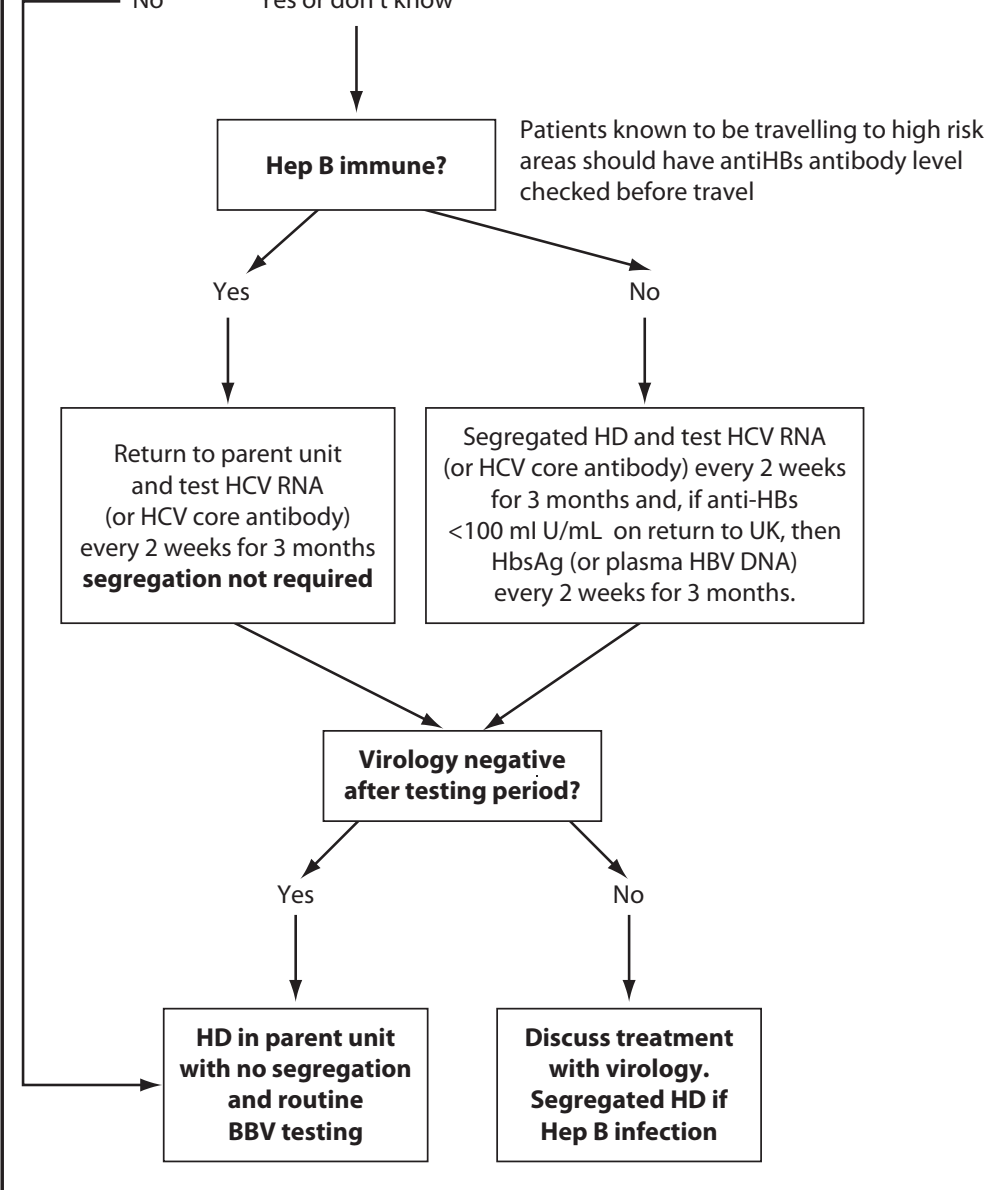

Hep Bs antibody $>100 \mathrm{ml} \mathrm{U} / \mathrm{mL}$ within last 12 months or antiHBc antibody present

Discuss with consultant and virologist

if necessary 